\title{
Export performance research: Where should we go next?
}

\author{
Piotr Trąpczyński, Henrik Mertens, David Peters, Krystian Barłożewski
}

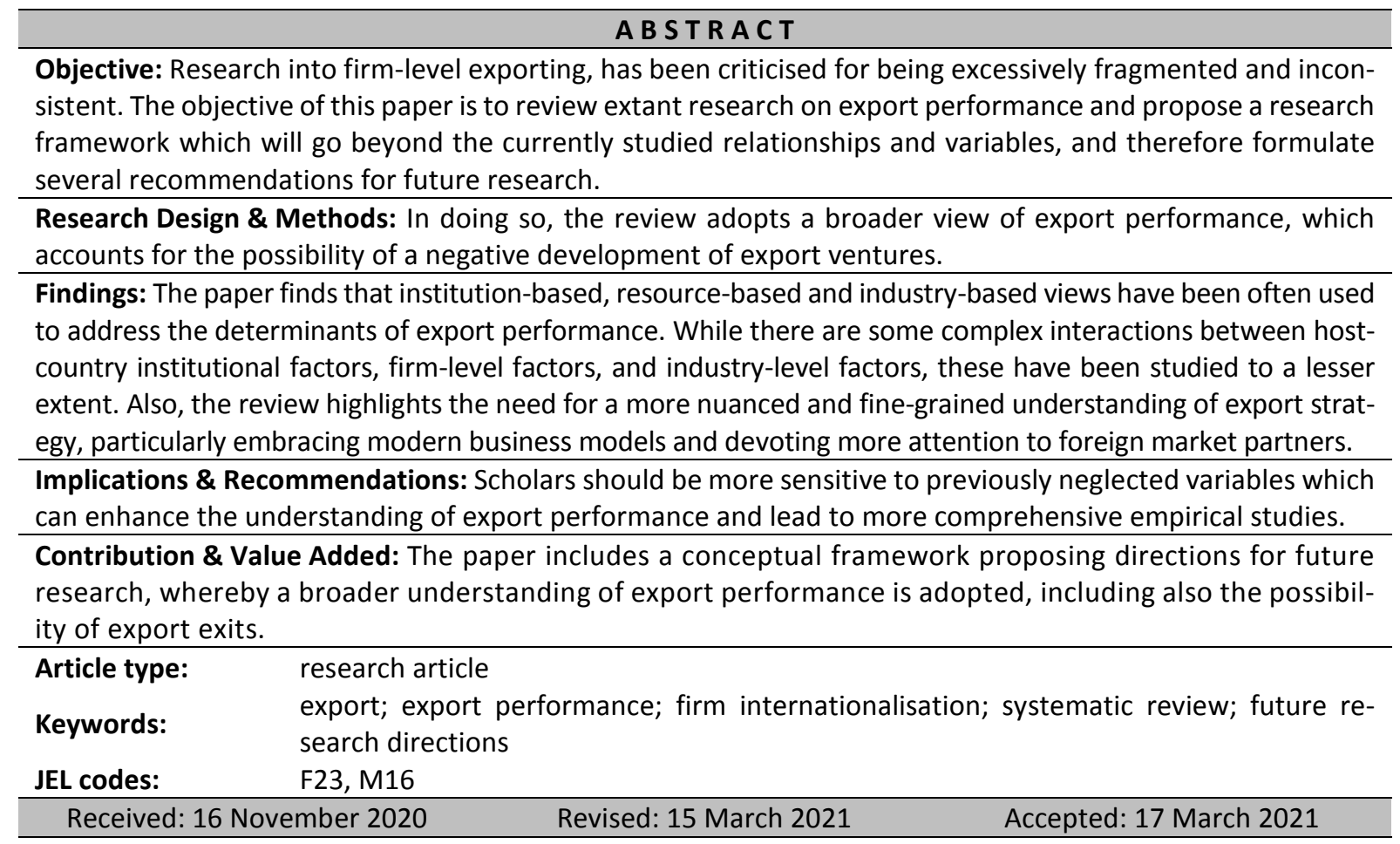

\section{Suggested citation:}

Trąpczyński, P., Mertens, H., Peters D., \& Barłożewski, K. (2021). Export performance research: Where should we go next?. International Entrepreneurship Review, 7(1), 59-72. https://doi.org/10.15678/ IER.2021.0701.05

\section{INTRODUCTION}

Export can be considered to be one of the most rapid and feasible methods of entering foreign market entry (Brache \& Felzenstein, 2019; Oliveira et al., 2018). Meanwhile, research into firm-level exporting has been inter alia criticised for being fragmented (Leonidou et al., 2010) and characterised by divergent results (Tan \& Sousa, 2013). While a number of theoretical concepts have been developed, single theories can only shed light on export performance in an isolated manner. As such, a systematic conceptual foundation embracing the determinants of export performance is still missing (Lages et al., 2008; Tan \& Sousa, 2013). Moreover, it is also less frequently discussed in extant research that export success is not guaranteed, as firms may discontinue exporting (Sousa \& Tan, 2015). Thus, the identification of antecedents of export performance is of key relevance both for exporting firms and the entire economy.

Accordingly, the objective of this article is to review extant studies on export performance and propose a conceptual framework which will go beyond the currently studied relationships and variables, and therefore allow formulating recommendations for future research. While there have been recent literature reviews devoted to export performance and its different antecedents (Chen et al., 
2016; Oliveira et al., 2012; Francioni et al., 2016), the aim of our present work is not to overlap with the previous diagnoses of the field, which already identified a plethora of determinants of export performance, their specific operationalisations or research designs. Nor is it to simplistically criticise extant research by merely highlighting what has been less explored. More importantly, we attempt to place export performance research in a broader context of IB research in order to highlight issues which could be addressed by scholars, which - as we argue - can help to advance this strand of IB research. We propose to consider studies on export survival and export exits as part of the same intertwined field. Not only has survival often been considered as a measure of export performance (Kadochnikov \& Fedyunina, 2017; Martuscelli \& Varela, 2018), but its antecedents and logic are important for understanding export success as a whole. Not least, export exit can affect exporting firm performance and its overall competitiveness, which is an aspect that goes beyond assessing the performance of a single export venture and allows decision makers to adopt a broader perspective on managing export markets. Still, exit research has developed separately, not allowing the two strands to build on each other and reap conceptual synergies that can drive new fruitful research questions.

The paper is organised as follows. The subsequent section explains the methodology of the conducted literature review. Next, a brief discussion of existing research on export performance ensues with focus on the main achievements and deficiencies of current research. Further, we introduce our conceptual framework which includes proposed research areas for further investigation. We discuss each of these areas in dedicated subsections.

\section{MATERIAL AND METHODS}

\section{Literature review design}

Existing literature reviews in the field of management have recurred to different methodologies, contingent on the objectives and topics of the literature review. In fact, the aim of this present review is not to devise an exhaustive quantitative overview of existing research on export performance, as such reviews can already be found (Chen et al., 2016; Francioni et al., 2016; Barłożewski \& Trąpczyński, 2021; Trąpczyński \& Halaszovich, 2021). Instead, the aim of the paper is to develop an overarching conceptual framework for studying export performance, based on the current shortcomings of this research and the proposals how to address them.

Within a systematic procedure, papers were identified in databases based on keywords. This stage was complemented with a manual lookup for printed materials, books, etc. A preliminary list of keywords developed based on general readings on export strategy, export organisation and export performance, it was subsequently expanded and adapted owing to the heterogeneity of the related vocabulary. Importantly, the search phrases also included export exits/withdrawals/survival or international/foreign market exit/withdrawal/survival. The search parameters were configured to include peer-reviewed papers published in academic journals between 1970 and 2020. ${ }^{1}$ This allowed for the scholarly discussion emerging on firm internationalisation in the 1970s to be incorporated in the review, but would eliminate a wide range of potentially irrelevant reference items from earlier years.

After the extraction of peer-reviewed scholarly journal articles from relevant academic databases using the EBSCO and ProQuest search engines, a screening process of the search results took place. After an initial examination of search results, criteria were established for exclusion of certain articles. Editorials and commentaries were excluded because they may be relevant to the topic, they usually do not contain specific scholarly sources or empirical evidence. Case studies without conceptualisation and analysis were excluded because they do not contain evaluation of the authors comparable to other papers. It was deemed appropriate to eliminate the need for non-systematic judgement and evaluation by the authors. The complete list of articles extracted from the search engines was reviewed and items not corresponding to the search criteria were removed from the list. This was done based on the titles, keywords and abstracts of the articles. A further iteration of filtering was implemented using the exclusion criteria, based on the full text of the articles.

\footnotetext{
${ }^{1}$ The literature review was completed by September 14, 2020.
} 


\section{Review sample description}

An initial search result of 379 articles extracted from the EBSCO and ProQuest search engines was further refined. The application of the aforementioned exclusion criteria led to the extraction of 285 relevant empirical articles for systematic analysis. Depicting the review sample by publication year, it becomes apparent that the time period from 2014-2016 featured 80 publications, whereas the highest year before 2014 was 2012 with 18 publications. The key factor to point out is that export performance seems to be a modern phenomenon, as $81 \%$ of all articles analysed were published after 2005 (see Figure 1).

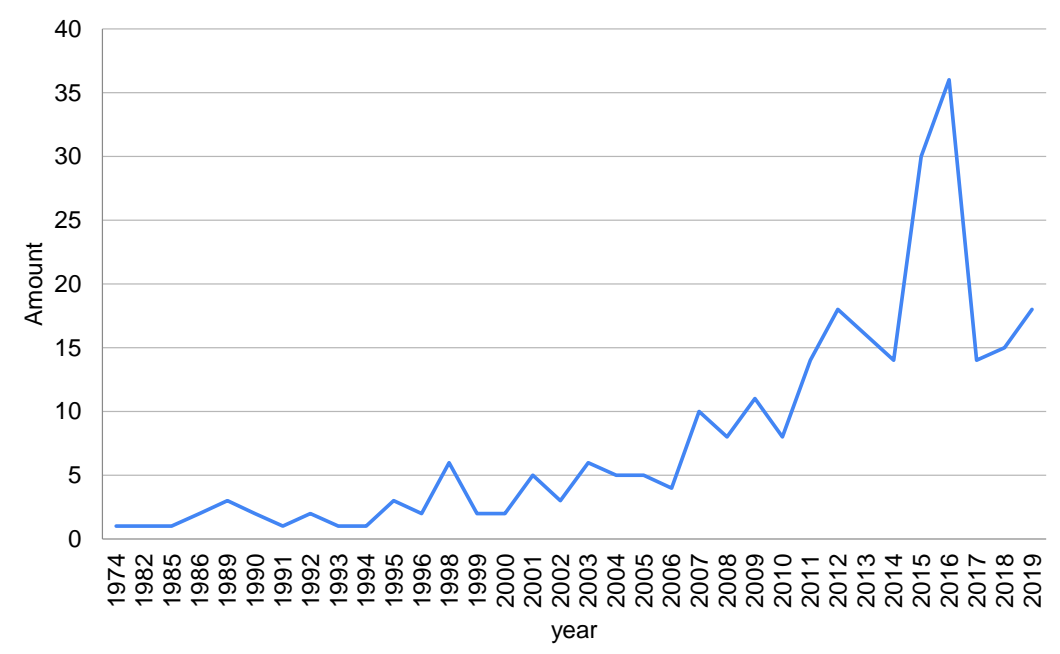

Figure 1. The evolution of export performance papers Source: own elaboration.

The majority of articles were featured in a huge variety of journals, with 123 journals featuring a total of 156 articles. The notable exceptions to the aforementioned rule are the International Business Review with 33 papers and the International Marketing Review with 32 papers (see Figure 2).

Of the 285 papers analysed, 240 used quantitative methods including structural equation modelling or various types of regression models, whereas only 12 used only qualitative analysis such as case studies. The remaining 33 articles used a mixture of qualitative and quantitative methods. 243 papers focused on export performance, whereas 42 put their emphasis on export withdrawals.

The detailed topical analysis reveals that inherent capabilities of the firm and strategy (consisting of the strategy process, overall strategy and the more specialised topic of marketing strategy adaptation) are most important with 73 and 80 papers respectively whilst environmental determinants and factors such as industry level determinants or host- or home country factors feature prominently with 43 articles as well (see Figure 3). The firm capabilities focus on factors that are internally related to the companies, starting from simple factors such as company size or organizational structure, but also including more complex topics such as managerial leaning towards exports or a company's ability for adaptation and learning. Strategic aspects researched in the papers start with general strategic decisions such as the choice of an export mode or strategy processes - e.g. the dynamics of the decision-making process regarding export entry and exit. They also include quite specific and detailed papers on the question of marketing strategy adaptation as a necessary antecedent to export and export performance.

The vast majority of the analysed papers focuses on antecedents \& outcomes of export performance, whilst only a small margin of 28 articles mentions the processes involved (see Figure 4). Generally, the antecedents involved are based on the question whether and how factors linked to the company or its surrounding environment are linked to the export performance of said company, whereas processes are more deeply involved in researching the tasks involved in a company achieving the target export performance. 

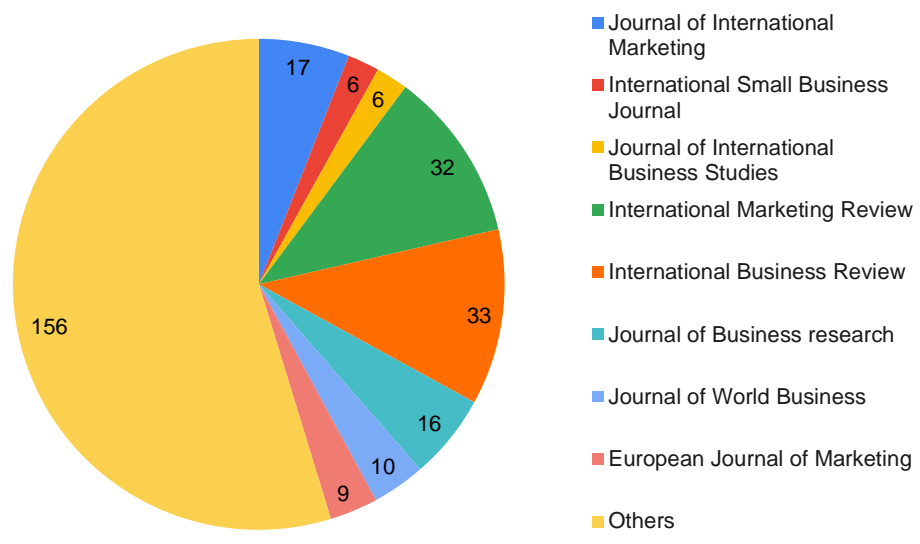

Figure 2. The distribution of papers by academic journals Source: own elaboration.

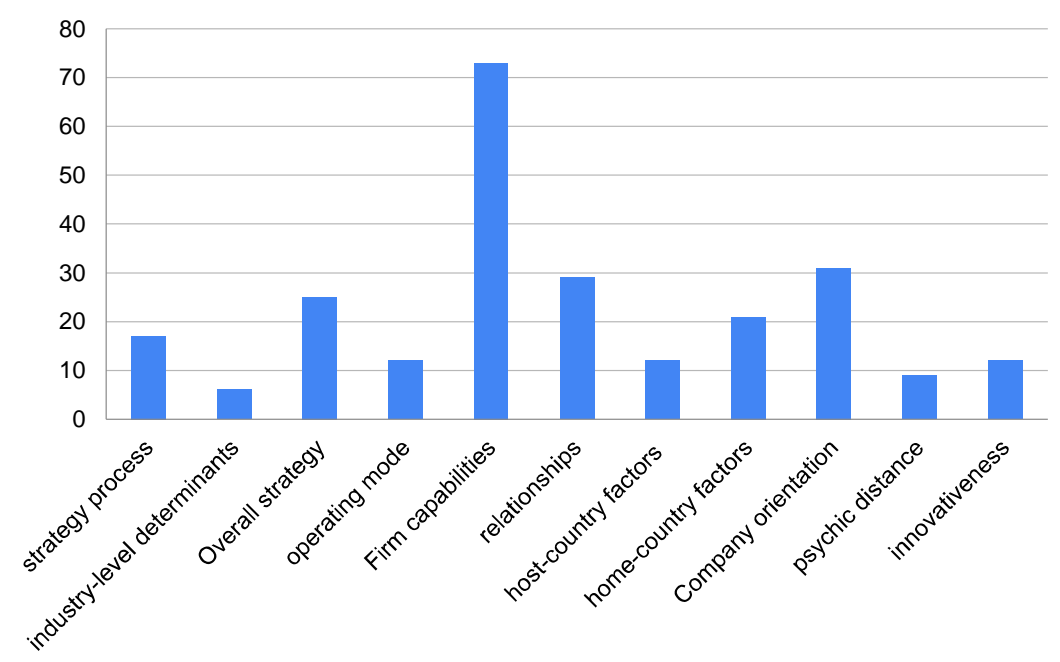

Figure 3. The leading topic areas of the analysed papers Source: own elaboration.

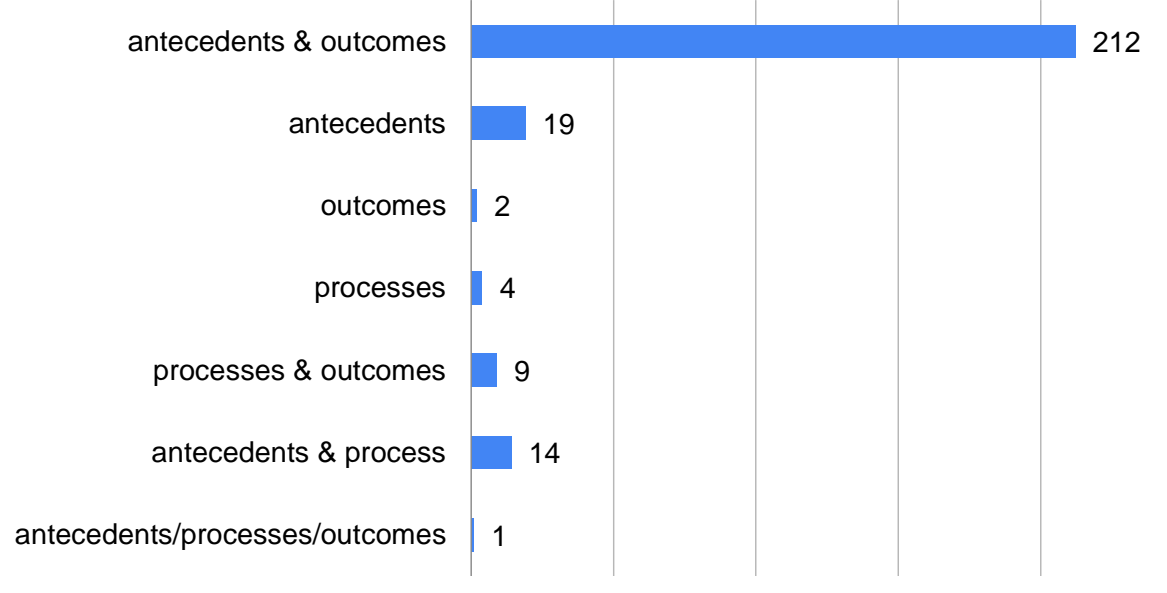

Figure 4. The leading research perspectives Source: own elaboration. 


\section{LITERATURE REVIEW}

\section{Major theoretical approaches and the resulting antecedents of export performance}

Taking a closer look at the home countries of export companies, it can safely be said that the existing research is strongly based on a Western perspective with 208 of 285 papers featuring companies exporting from Europe, America or Australia. In total, 67 different countries were analysed with the UK taking the top spot with 24 papers, closely followed by Spain with 20 articles and China with 18 articles. A possible reason for such a focus on the UK and Spain can be found in the ties to export market by history and language, factors that are connecting both home countries (see Figure 5).

A number of conceptual approaches have been applied in extant research thus far. First, the industry-based view links firm performance to industry conditions (Porter, 1980). In the majority of identified export papers multiple industries have been considered, which allows controlling for sectoral specificity and generalising the research findings (Chen et al., 2016). With regard to factors related to the foreign market, the intensity of competition has gained visible research attention, albeit with conflicting findings. The level of competition which firms need to confront in foreign markets has broadly been considered to have a positive effect upon marketing strategy adaptation because of the pressure exerted by the competition (Cui \& Lui, 2005; Lages et al., 2008). In this context, some scholars find a positive linkage between the standardisation of marketing strategy standardisation and the level of competitive intensity (Katsikeas et al., 2006). However, the relevance of the context of the industry for further decisions, such as the choice of export locations and export models, and the performance repercussions thereof, have been studied far less.

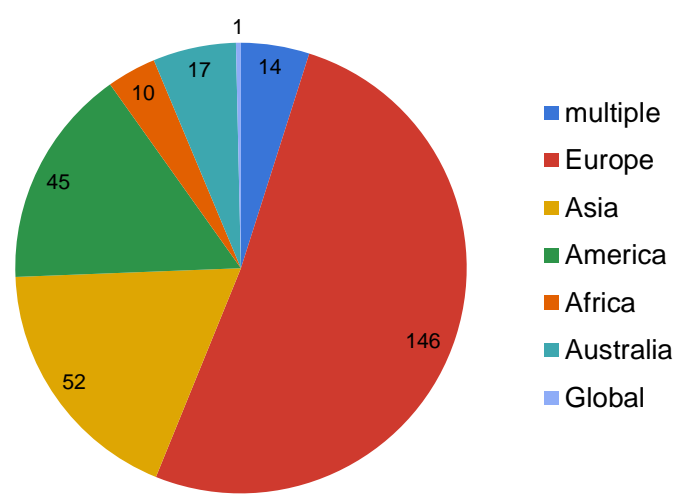

Figure 5. The home countries of the reviewed papers Source: own elaboration.

Second, the resource-based view (RBV) indicates that differences between companies account for the adopted strategy and its outcomes (Barney, 1991). The RBV regards an organisation as an individual pool of value-generating resources, both tangible and intangible, which explain a firm's competitive position in international markets (Barney et al., 2001; Katsikeas et al., 2000). In this vein, Cadogan et al. (2009) show that the market orientation of a firm is conducive to its export performance. However, many studies on firm internationalisation have focused on firm capabilities in the understanding of intangible assets, with a particular focus on product innovation or brand equity, devoting less attention to further sources of competitive advantage, such as the organisation of export activities, the ability to adjust export behaviour to foreign market conditions, or experience-based advantage, which may be an asset of firms from economies only recently having joined the international business environment (Cuervo-Cazurra \& Genc, 2008).

The third influential perspective, the institution-based view emphasises the importance of institutional environment as a determinant of corporate behaviour and performance (Dacin et al., 2002). Influenced by North (1990) and Scott (1995), This perspective argues that internationalisation behaviour results from an interplay between institutions and organisations. Thus, firm strategy emerges not only as 
a result of an interplay of firm-specific and industry-factors, but also of formal and informal institutional conditions that firms come across in a foreign market (Peng, 2006). Accordingly, empirical evidence suggests that a high quality of the institutional environment enhances export performance (Lipuma et al., 2013). With regard to informal institutional differences among countries, a significant number of related studies come to the conclusion that psychic distance between countries leads to a higher level of offer adaptation (Sousa \& Bradley, 2005; Sousa \& Lengler, 2009; Sousa \& Lages, 2011). Hereby, psychic distance pertains to all factors affecting foreign activities by hindering information flows. One of the key problems of extant research, however, may be the predominant focus on the magnitude of perceived distance, instead of taking into account the direction of differences, i.e. either more or less developed countries as opposed to the home market (Shenkar, 2001).

Further, governmental export promotion is considered as a vital resource to engage in export activities for many exporters, in particular small and medium enterprises (SMEs) (Durmuşoğlu et al., 2012). Leonidou et al. (2011) argue that export promotion and assistance are one of the aspects that have attracted comparably scarce research efforts thus far. For many governments, an active promotion of export activities is a strategic goal. However, scientific evidence about the effectiveness of these programs remains unclear. While some authors report positive effects, other studies find no or even negative effects (Durmuşoğlu et al., 2012). In fact, the effectiveness of different measures varies greatly (Alvarez, 2004; Durmuşoǧlu et al., 2012; Wilkinson \& Brouthers, 2006).

\section{Export channels and international marketing strategy}

Apart from the motives, stimuli and barriers to exporting, the strategic aspects of exporting and their performance consequences for the exporter have been considered as a key area of interest (Cieślik et al., 2015; Leonidou et al., 2010). One of the focal aspects in this research field is the degree of foreign market strategy adaptation or standardisation, regardless of which mode of market entry was adopted (Theodosiou \& Leonidou, 2003). Yet, extant studies remain inconclusive with regard to whether adaptation or standardisation leads to superior outcomes, and under which specific conclusions (Chen et al., 2016).

In extant literature on exporting there have been several attempts at conceptualising foreign market strategy (Klein \& Roth, 1990; Li et al., 2017; Peng et al., 2006). Apart from the issue of organisation of exporting activities, most studies focused on whether to standardise or adapt the export marketing strategy (Morgan et al., 2012). Thereby, they usually examined merely some selected dimensions of the marketing strategy, while overlooking potential interrelationships in or adapting them. For instance, Tan and Sousa (2013) find that product standardisation has a negative impact upon foreign market performance, although the effect of promotion standardisation is not significant, whilst the standardisation of price and distribution standardisation positively affect performance.

Moreover, the degree of adaptation was in many instances studied from a general perspective, without considering more detailed aspects of the strategy. For instance, promotion was in some cases decomposed into advertising, sales promotions or PR, yet scholars have unsuccessfully called for more fine-grained conceptualisations (Theodosiou \& Leonidou, 2003). We find that almost no research on exporting has referred to the concept of the business model (Zott et al., 2011; Hennart, 2014), instead focusing on selected marketing strategy aspects.

\section{Avenues for further research}

Based on the conducted review of extant research and the relative paucity of specific aspects and their interrelations, we propose to intensify research efforts along three dimensions (see Figure 6):

- antecedents (at exporting firm level, export venture level including the perspective of foreign market partners, as well as external determinants including home and host country factors);

- outcomes, including different levels of performance as well as export survival/exit and its broader implications;

- process perspective, putting export performance into a broader context which has been frequently neglected in extant research. 


\section{Level 1: antecedents}

\section{Institutional home- and host-country determinants}

The current rise of scepticism towards globalisation poses new challenges towards firms and economic policy-makers alike and calls for a more complete consideration of the institutional determinants of the internationalisation of firms and economies. The understanding of export antecedents in diverse institutional settings is the more so relevant that it has been agreed that there is a causal relationships between export expansion and economic growth (Dunning \& Lundan, 2008; Mah, 2005). Export performance can be driven by the extent of institutional differences between home and host countries, which can be positive if a given host country is more advanced than the home country, or negative if the host country is less developed as compared to the home market of the exporter. Although earlier research has devoted attention to the magnitude of institutional distance, the aforesaid direction of research depending on whether an export market is institutionally more or less developed as compared to the home country, has remained far less explored (Cuervo-Cazurra \& Genc, 2008). Future research can contribute to reducing this gap by accounting for the type of institutional environments to which exporters expand. A potential explanation for the incongruence of the findings might yield from the different country contexts used in the studies. As was shown in other studies, the location of exporters impacts their performance (Freeman et al., 2012). The relevance of locations, thereby, is based on the location specific opportunities to access resources and networks (Halaszovich \& Lundan, 2016).

The relevance of the specific context is further strengthened by findings that illustrate a mismatch between the governmental programs and the actually needs of firms (Seringhaus \& Botschen, 1991). For those firms who incorporate export promotion, the interdependencies with the other elements of the business model seem to matter for their effectiveness. This interaction, so far, has not been addressed in the academic literature. To adjust the programs with the exporters' business models, governmental export promotion agencies and exporters have to engage in co-evolutionary processes, as described by Cantwell et al. (2010) in the broader field of institutional co-evolution and foreign direct investments. Moreover, the efficiency of governmental export promotion depends on the individual export models of the exporting firms, which has not been addressed in the academic literature. Thus, scholars can plausibly contribute to extant research by more explicitly considering the significance of home-country institutional support for export performance in conjunction with firm- and industry-level variables.

\section{Industry-level determinants}

A number of studies examining export behaviour adaptation have looked into the product features such as its type, cost, or positioning (Myers \& Cavusgil, 1996). The majority of research suggests that a standardised approach is more appropriate in the case of industrial rather than consumer products, as less adaptation is required. Notwithstanding, extant evidence on the effect of the product type on the degree of standardisation of export marketing is not consistent (Cavusgil \& Zou, 1994). The present focus on product characteristics and fulfilled needs does not provide a complete image of contemporary strategies of competing in international markets (Dhanaraj \& Beamish, 2003). We argue that a more explicit consideration for the role of technological intensity, which reflects the advancement of products and thus the relative suitability of certain export markets in relation to others, should shed more light on the logic and success factors of exports in different institutional locations.

\section{Exporting firm and export market business models}

As highlighted above, export behaviour has been predominantly conceptualised with simple dimensions of marketing strategy or level of channel integration, neglecting further performance-affecting dimensions related to the implementation of exports, such as export logistics and the use of information technology (particularly e-commerce) for export development. Future studies should contribute to extant research by adopting a broader concept of export model, including channel integration, use of modern distribution and sales concepts, in addition to the previous understanding of market 
strategy used in export research. Moreover, the role of foreign partners who take over a number of responsibilities in export market operations requires more attention, particularly with regard to their influence on foreign market strategy and its evolution over time.

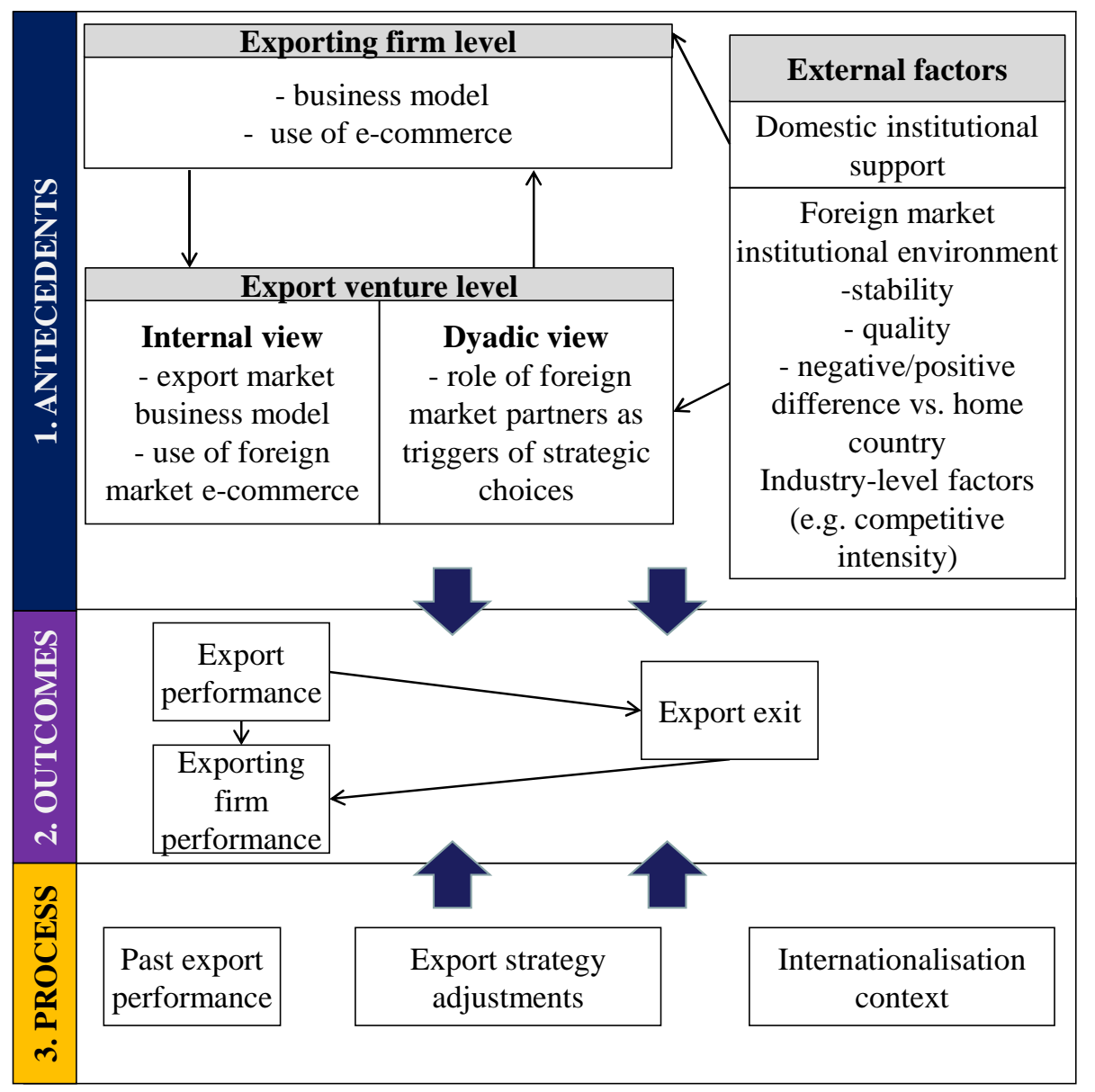

Figure 6. Export performance research framework

Source: own elaboration.

Moreover, a significant number of studies have regarded foreign market strategy and its adaptation as a mediator of some firm-level variables (such as marketing capabilities) or host-country level variables, such as distance in its various dimensions, on export performance, using perceptual measures in such research designs. However, as Brouthers (2013) argues, performance is affected by objective variables, while strategic choices are influenced by managerial perceptions. Thus, it may be a worthwhile avenue to investigate the influence of objective host-country factors, moderated by firmlevel factors, particularly different dimensions of the business model.

\section{Level 2: outcomes}

\section{Export performance and exporting firm performance}

Most studies devoted to export performance have concentrated on such dimensions as export intensity, export sales, export profitability, or export sales growth (Tan \& Sousa, 2013). Non-financial performance measures, such as export performance satisfaction or the accomplishment of export objectives, are less frequently employed (Chen et al., 2016). Noticeably, many extant studies merely recur to a single performance indicator, thereby neglecting the multi-dimensional nature of export. Besides, firms learn from their prior export commitments in order to grasp the causality between specific foreign market conditions, appropriate strategic behaviour and its performance outcomes (Lages et al., 2008). Indeed, it has been implied by scholars that the performance of export operations in a given 
year has a bearing on the export strategy decisions in the subsequent year as a result of organisational learning (Lages et al., 2008).

To summarise, the role of export success on its subsequent evolution has not been studied to date. IB scholars need to go beyond the hitherto predominant focus on export performance as economic results of a given venture, and consider both export withdrawals and their determinants as an expression of export sustainability. Moreover, research designs will need to be re-adjusted to also examine the entire exporting firm performance as an outcome of overall export behaviour and choices of foreign institutional contexts.

\section{Export exits and their long-term implications}

We argue that export learning and adaptation of the foreign operations can also lead to temporary or permanent reduction of export activity or withdrawal from the foreign market (Freeman et al., 2013). However, the recognition of this - at first glance - negative development of international operations is very rare in existing research. While studies have shown that difficulties faced by the firm in the foreign market, as well as internal resource limitations or deficiencies can increase the likelihood of export exit, as does the lack of strategic fit of the firm with its environment (Sousa \& Tan, 2015). Pauwels and Matthyssens (2004) indicate that withdrawal from an export market may lead to strategic renewal in the exporting firm. However, the existing conceptualisation of export activities has inadequately considered exporting as part of its overall strategic development (Leonidou et al., 2010). Currently, a very limited number of studies could be found that explicitly analyse product-related international decisions and their antecedents (Owen \& Yawson, 2006; lavocone \& Javorcik, 2010).

Yet, while it is relatively common in divestment research to study implications for the firms (e.g. Lee \& Madhavan, 2010), more research seems relevant to shed more light on the non-financial, competitiveness-related consequences of the different forms export reduction or exit in the long term. Few studies, such as Baldwin and Yan (2012) considered firm performance after export market exit decision depending on whether firms re-internationalise or maintain a reduced international footprint. This is an aspect which clearly deserves further investigation.

Pauwels and Matthyssens (2004), in turn, analysed strategic export market withdrawal within firm internationalisation, incorporating strategic flexibility in the process model. They also identify costrelated effects of export exit (Pauwels \& Matthyssens, 1999). For instance, strategic re-structuring creates an opportunity for firms to service their export markets more cost-effectively, by entering collaborative arrangements with local competitors (Freeman et al., 2013).

\section{Level 3: process perspective}

The contingency view implies that export performance is driven by the contingent compatibility, which is changeable and individualised to every company or export venture (Hultman et al., 2011). As it has been noted in the previous section, the organisational learning theory refers to the linkages between previous organisational actions and the subsequent strategic choices and performance (Santos-Vijande et al., 2012).

However, while export performance research has acknowledged the role of past experience on current export strategy and performance, this role has not been explored in a sufficiently nuanced manner. And yet, since the overall experience of operating in international markets is not always market-specific and hence its applicability to foreign contexts may be limited, also its role for performance may not be as pronounced (Guillen \& Garcia-Canal 2009). On the other hand, research suggests that different modes of foreign market entry result in different types of experience (Gao et al., 2008). Moreover, experience gained in an institutionally similar context to the foreign market under study has different implications than for a dissimilar one (Trąpczyński \& Banalieva, 2016). Clearly, extant export performance research has neglected the direction and type of experience of exporters. Thus, more research is warranted to contribute to this gap by studying different types of experience and their effects on export performance. 


\section{CONCLUSIONS}

The literature review and the identified gaps in extant research performance research lead to the development of a conceptual framework which may be useful in guiding future research in the field. As discussed earlier, the purpose of the framework is by no means to provide an exhaustive collection of export performance determinants, nor to categorize their relationships in a technical manner (i.e., whether they must be included as moderators or mediators, etc.), but more importantly to propose in what ways we can advance IB research by recurring to some already known theoretical concepts. Thereby, several advancements can be made:

1. scholars may become more sensitive to previously neglected variables which can enhance the understanding of export performance, particularly those related to the business model of the exporter, as well as the changes in this model with regard to foreign markets,

2. it may become more apparent that the hitherto isolated research strands employing distinct variables can be integrated within consistent theoretical frameworks,

3. export performance cannot be understood as a narrow, isolated concept, but has some important effects on the success of the entire exporting firm

4. as firm internationalisation may not be linear, also export performance research should acknowledge export exits as an inherent development option, which both affects performance, and can actually be regarded as its manifestation.

\section{REFERENCES}

Alvarez, R. (2004). Sources of export success in small-and medium-sized enterprises: the impact of public programs. International Business Review, 13(3), 383-400. https://doi.org/10.1016/j.ibusrev.2004.01.002

Baldwin, J., \& Yan, B. (2012). Market expansion and productivity growth: Do new domestic markets matter as much as new international markets?. Journal of Economics \& Management Strategy, 21(2), 469-491. https://doi.org/10.1111/j.1530-9134.2012.00330.x

Barłożewski, K., \& Trąpczyński, P. (2021). Internationalisation motives and the multinationality-performance relationship: The case of Polish firms. Entrepreneurial Business and Economics Review, 9(2), 85-104. https://doi.org/10.15678/EBER.2021.090206

Barney, J. (1991). Firm resources and sustained competitive advantage. Journal of Management, 17(1), 99-120. https://doi.org/10.1177/014920639101700108

Barney, J., Wright, M., \& Ketchen Jr, D. J. (2001). The resource-based view of the firm: Ten years after 1991. Journal of Management, 27(6), 625-641. https://doi.org/10.1177/014920630102700601

Brache, J., \& Felzensztein, C. (2019). Geographical co-location on Chilean SME's export performance. Journal of Business Research, 105, 310-321. https://doi.org/10.1016/j.jbusres.2017.11.044

Brouthers, K.D. (2013). A retrospective on: Institutional, cultural and transaction cost influences on entry mode choice and performance. Journal of International Business Studies, 44(1), 14-22. https://doi.org/10.1057/jibs.2012.23

Cadogan, J. W., Kuivalainen, O., \& Sundqvist, S. (2009). Export market-oriented behavior and export performance: quadratic and moderating effects under differing degrees of market dynamism and internationalization. Journal of International Marketing, 17(4), 71-89. https://doi.org/10.1509/jimk.17.4.71

Cantwell, J., Dunning, J. H., \& Lundan, S. M. (2010). An evolutionary approach to understanding international business activity: The co-evolution of MNEs and the institutional environment. Journal of International Business Studies, 41(4), 567-586. https://doi.org/10.1057/jibs.2009.95

Cavusgil, S. T., \& Zou, S. (1994). Marketing strategy-performance relationship: an investigation of the empirical link in export market ventures. Journal of Marketing, 58(1), 1-21. https://doi.org/10.1177/002224299405800101

Chen, J., Sousa, C. M., \& He, X. (2016). The determinants of export performance: a review of the literature 20062014. International Marketing Review, 33(5), 626-670. https://doi.org/10.1108/IMR-10-2015-0212 
Cieślik, J., Kaciak, E., \& Thongpapanl, N. T. (2015). Effect of export experience and market scope strategy on export performance: Evidence from Poland. International Business Review, 24(5), 772-780. https://doi.org/10.1016/j.ibusrev.2015.02.003

Cuervo-Cazurra, A., \& Genc, M. (2008). Transforming disadvantages into advantages: developing-country MNEs in the least developed countries. Journal of International Business Studies, 39(6), 957-979. https://doi.org/10.1057/palgrave.jibs.8400390

Cui, G., \& Lui, H. K. (2005). Order of entry and performance of multinational corporations in an emerging market: A contingent resource perspective. Journal of International Marketing, 13(4), 28-56. https://doi.org/10.1509/jimk.2005.13.4.28

Dacin, M. T., Goodstein, J., \& Scott, W. R. (2002). Institutional theory and institutional change: introduction to the special research forum. The Academy of Management Journal, 45(1), 43-56. https://doi.org/10.5465/amj.2002.6283388

Dhanaraj, C., \& Beamish, P. W. (2003). A resource-based approach to the study of export performance. Journal of Small Business Management, 41(3), 242-261. https://doi.org/10.1111/1540-627X.00080

Dunning, J. H., \& Lundan, S. M. (2008). Multinational enterprises and the global economy. Edward Elgar Publishing.

Durmuşoğlu, S. S., Apfelthaler, G., Nayir, D. Z., Alvarez, R., \& Mughan, T. (2012). The effect of governmentdesigned export promotion service use on small and medium-sized enterprise goal achievement: A multidimensional view of export performance. Industrial Marketing Management, 41(4), 680-691. https://doi.org/10.1016/j.indmarman.2011.09.016

Francioni, B., Pagano, A., \& Castellani, D. (2016). Drivers of SMEs' exporting activity: a review and a research agenda. Multinational Business Review, 24(3), 194-215. https://doi.org/10.1108/MBR-06-2016-0023

Freeman, J., Styles, C., \& Lawley, M. (2012). Does firm location make a difference to the export performance of SMEs?. International Marketing Review, 29(1), 88-113. https://doi.org/10.1108/02651331211201552

Freeman, S., Deligonul, S., \& Cavusgil, T. (2013). Strategic re-structuring by born-globals using outward and inwardoriented activity. International Marketing Review, 30(2), 156-182. https://doi.org/10.1108/02651331311314574

Gao, G., Pan, Y., Lu, J., \& Tao, Z. (2008). Performance of Multinational Firms' Subsidiaries: Influences of Cumulative Experience. Management International Review, 48(6), 749-768. https://doi.org/10.1007/s11575-008-0105-x

Guillén, M. F., \& García-Canal, E. (2009). The American model of the multinational firm and the "new" multinationals from emerging economies. The Academy of Management Perspectives, 23(2), 23-35. https://doi.org/10.5465/amp.2009.39985538

Halaszovich, T. F., \& Lundan, S. M. (2016). The moderating role of local embeddedness on the performance of foreign and domestic firms in emerging markets. International Business Review, 25(5), 1136-1148. https://doi.org/10.1016/j.ibusrev.2016.02.003

Hennart, J. F. (2014). The accidental internationalists: a theory of born globals. Entrepreneurship Theory and Practice, 38(1), 117-135. https://doi.org/10.1111/etap.12076

Hultman, M., Katsikeas, C.S., \& Robson, M. J. (2011). Export promotion strategy and performance: the role of international experience. Journal of International Marketing, 19(4), 17-39. https://doi.org/10.1509/jim.11.0022

lacovone, L., \& Javorcik, B.S. (2010). Multi-Product Exporters: Product Churning, Uncertainty and Export Discoveries. The Economic Journal, 120, 481-499. https://doi.org/10.1111/j.1468-0297.2010.02356.x

Kadochnikov, S. M., \& Fedyunina, A. A. (2017). The impact of financial and human resources on the export performance of Russian firms. Economic Systems, 41(1), 41-51. https://doi.org/10.1016/j.ecosys.2016.11.001

Katsikeas, C. S., Leonidou, L. C., \& Morgan, N. A. (2000). Firm-level export performance assessment: review, evaluation, and development. Journal of the Academy of Marketing Science, 28(4), 493-511. https://doi.org/10.1177/0092070300284003

Katsikeas, C. S., Samiee, S., \& Theodosiou, M. (2006). Strategy fit and performance consequences of international marketing standardization. Strategic Management Journal, 27(9), 867-890. https://doi.org/10.1002/smj.549

Klein, S., \& Roth, V. J. (1990). Determinants of export channel structure: The effects of experience and psychic distance reconsidered. International Marketing Review, 7, 27-38. https://doi.org/10.1108/EUM0000000001533

Lages, L. F., \& Montgomery, D. B. (2004). Export performance as an antecedent of export commitment and marketing strategy adaptation: Evidence from small and medium-sized exporters. European Journal of Marketing, 38(9/10), 1186-1214. https://doi.org/10.1108/03090560410548933 
Lages, L. F., Jap, S. D., \& Griffith, D. A. (2008). The role of past performance in export ventures: a short-term reactive approach. Journal of International Business Studies, 39(2), 304-325. https://doi.org/10.1057/palgrave.jibs. 8400339

Lee, D., \& Madhavan, R. (2010). Divestiture and Firm Performance: A Meta-Analysis. Journal of Management, 36(6), 1345-1371. https://doi.org/10.1177/0149206309360931

Leonidou, L. C., Katsikeas, C. S., \& Coudounaris, D. N. (2010). Five decades of business research into exporting: A bibliographic analysis. Journal of International Management, 16(1), 78-91. https://doi.org/10.1016/j.intman.2009.06.001

Leonidou, L. C., Palihawadana, D., \& Theodosiou, M. (2011). National Export-Promotion Programs as Drivers of Organizational Resources and Capabilities: Effects on Strategy, Competitive Advantage, and Performance. Journal of International Marketing, 19(2), 1-29. https://doi.org/10.1509/jimk.19.2.1

Li, M., He, X., \& Sousa, C. M. (2017). A review of the empirical research on export channel selection between 1979 and 2015. International Business Review, 26(2), 303-323. https://doi.org/10.1016/j.ibusrev.2016.09.001

Lipuma, J. A., Newbert, S. L., \& Doh, J. P. (2013). The effect of institutional quality on firm export performance in emerging economies: a contingency model of firm age and size. Small Business Economics, 40(4), 817-841. https://doi.org/10.1007/s11187-011-9395-7

Mah, J. S. (2005). Export expansion, economic growth and causality in China. Applied Economics Letters, 12(2), 105-107. https://doi.org/10.1080/1350485042000314343

Martuscelli, A., \& Varela, G. (2018). Survival is for the fittest: Export survival patterns in Georgia. Economic Systems, 42(3), 397-413. https://doi.org/10.1016/j.ecosys.2017.10.002

Morgan, N. A., Katsikeas, C. S., \& Vorhies, D. W. (2012). Export marketing strategy implementation, export marketing capabilities, and export venture performance. Journal of the Academy of Marketing Science, 40, 271289. https://doi.org/10.1007/s11747-011-0275-0

Myers, M. B., \& Cavusgil, S. T. (1996). Export pricing strategy-performance relationship: a conceptual framework. Advances in International Marketing, 8, 159-178

North, D. C. (1990). Institutions, Institutional Change, and Economic Performance. Cambridge and New York: Cambridge University Press. https://doi.org/10.1017/СBO9780511808678

Oliveira, J. S., Cadogan, J. W., \& Souchon, A. (2012). Level of analysis in export performance research. International Marketing Review, 29(1), 114-127. https://doi.org/10.1108/02651331211201561

Oliveira, J. S., Yazdani, N., Cadogan, J. W., Hodgkinson, I. R., Tsougkou, E., Story, V. M., \& Boso, N. (2018). The empirical link between export entry mode diversity and export performance: A contingency-and institutionalbased examination. Journal of Business Research, 88, 505-512. https://doi.org/10.1016/j.jbusres.2017.12.001

Owen, S., \& Yawson, A. (2006). Domestic or International: Divestitures in Australian Multinational Corporations. Global Finance Journal, 17, 282-293. https://doi.org/10.1016/j.gfj.2006.04.002

Pauwels, P. \& Matthyssens, P. (2004). Strategic flexibility in export expansion: growing through withdrawal. International Marketing Review, 21(4/5), 496-510. https://doi.org/10.1108/02651330410547162

Pauwels, P., \& Matthyssens, P. (1999). A Strategy Process Perspective on Export Withdrawal. Journal of International Marketing, 7(3), 10-37. https://doi.org/10.1177/1069031X9900700304

Peng, M. W., Zhou, Y., \& York, A. S. (2006). Behind make or buy decisions in export strategy: A replication and extension of Trabold. Journal of World Business, 41(3), 289-300. https://doi.org/10.1016/j.jwb.2006.01.006

Peng, M. W. (2006). Global strategy. Cincinnati, OH: Thomson South-Western.

Porter, M. E. (1980). Competitive strategy: Techniques for analyzing industries and competition. Free Press.

Santos-Vijande, M. L., López-Sánchez, J., \& Trespalacios, J. A. (2012). How organizational learning affects a firm's flexibility, competitive strategy, and performance. Journal of Business Research, 65(8), 1079-1089. https://doi.org/10.1016/j.jbusres.2011.09.002

Scott, W.R. (1995). Institutions and Organizations. Thousand Oaks, CA: Sage.

Seringhaus, F. H. R., \& Botschen, G. (1991). Cross-National Comparison of Export Promotion Services: The Views of Canadian and Austrian Companies. Journal of International Business Studies, 22(1), 115-133

Shenkar, O. (2001). Cultural distance revisited: Towards a more rigorous conceptualization and measurement of cultural differences. Journal of International Business Studies, 32(3), 519-535. https://doi.org/10.1057/jibs.2011.40 
Sousa, C. M. P., \& Tan, Q. (2015). Exit from a foreign market: do poor performance, strategic fit, cultural distance, and international experience matter?. Journal of International Marketing, 23(4), 84-104. https://doi.org/10.1509/jim.15.0003

Sousa, C. M., \& Bradley, F. (2005). Global markets: does psychic distance matter?. Journal of Strategic Marketing, 13(1), 43-59. https://doi.org/10.1080/0965254042000328668

Sousa, C. M., \& Lages, L. F. (2011). The PD scale: a measure of psychic distance and its impact on international marketing strategy. International Marketing Review, 28(2), 201-222. https://doi.org/10.1108/02651331111122678

Sousa, C. M., \& Lengler, J. (2009). Psychic distance, marketing strategy and performance in export ventures of Brazilian firms. Journal of Marketing Management, 25(5-6), 591-610. https://doi.org/10.1362/026725709X461876

Tan, Q., \& Sousa, C. M. (2013). International marketing standardization. Management International Review, 53(5), 711-739. https://doi.org/10.1007/s11575-013-0172-5

Theodosiou, M., \& Leonidou, L. C. (2003). Standardization versus adaptation of international marketing strategy: an integrative assessment of the empirical research. International Business Review, 12(2), 141-171. https://doi.org/10.1016/S0969-5931(02)00094-X

Trąpczyński, P., \& Banalieva, E. R. (2016). Institutional difference, organizational experience, and foreign affiliate performance: Evidence from Polish firms. Journal of World Business, 51(5), 826-842. https://doi.org/10.1016/j.jwb.2016.07.013

Trąpczyński, P., \& Halaszovich, T. (2021). Exploitation-exploration balance and its performance outcomes: A study of FDI portfolio decisions of new multinationals. Entrepreneurial Business and Economics Review, 9(4). Ahead-of-Print.

Wilkinson, T., \& Brouthers, L. E. (2006). Trade promotion and SME export performance. International Business Review, 15(3), 233-252. https://doi.org/10.1016/j.ibusrev.2006.03.001

Zott, C., Amit, R., \& Massa, L. (2011). The business model: recent developments and future research. Journal of Management, 37(4), 1019-1042. https://doi.org/ 10.1177/0149206311406265 


\section{Authors}

The contribution share of authors is equal and amounted to $25 \%$ for each of them.

\section{Piotr Trąpczyński}

Associate Professor at the Poznań University of Economics and Business, Department of International Competitiveness at the Institute of International Business and Economics. His research interests include foreign direct investments and divestments, export performance and export exits, along with business models.

Correspondence to: Dr hab. Piotr Trąpczyński, prof. UEP, Department of International Competitiveness, Poznań University of Economics and Business, al. Niepodległości 1, 61-875 Poznań, Poland, e-mail: piotr.trapczynski@ue.poznan.pl

ORCID (1) http://orcid.org/0000-0001-8154-9174

\section{Henrik Mertens}

Doctoral Candidate at the Poznań University of Economics and Business, holds a Master's degree of the Alpen Adria University Klagenfurt, Austria. He has a track record of professional experience in business analytics and controlling. His research interests include foreign market relationships and performance.

Correspondence to: Mr. Henrik Mertens, Hochsteingasse 9/9, 8010, Graz, Austria, e-mail: henrik.mertens@mertens-nord.de

ORCID (1) http://orcid.org/0000-0002-2847-5468

\section{David Peters}

Doctoral Candidate at the Poznań University of Economics and Business, holds a Master's degree of the RuhrUniversität Bochum, Germany. He has corporate work experience in the area of financial controlling. His research interests revolve around the linkages between the (de-)internationalisation of the firm and its performance.

Correspondence to: Mr. David Peters, Schellstr. 10, 44789 Bochum, Germany, e-mail: david.peters1991@web.de ORCID (1) http://orcid.org/0000-0002-4744-5598

\section{Krystian Barłożewski}

Assistant Professor at the Warsaw School of Economics, Department of International Management at the Collegium of World Economy. His research interests include internationalization performance and the impact of digital transformation on internationalization models and processes.

Correspondence to: dr Krystian Barłożewski, Department of International Management, Collegium of World Economy, Warsaw School of Economics, ul. Madalińskiego 6/8, 02-513 Warszawa, Poland, e-mail: kbarlo@sgh.waw.pl ORCID (i) http://orcid.org/0000-0002-7050-0962

\section{Acknowledgements and Financial Disclosure}

This paper was prepared within a research project financed by the research grant of the National Science Centre (Poland) awarded based on the decision no. DEC-2017/27/B/HS4/02344.

\section{Conflict of Interest}

The authors declare that the research was conducted in the absence of any commercial or financial relationships that could be construed as a potential conflict of interest.

\section{Copyright and License}

This article is published under the terms of the Creative Commons

Attribution - NoDerivs (CC BY-ND 4.0) License

http://creativecommons.org/licenses/by-nd/4.0/ 